\title{
Effects of Calcium Salts on Apple Bitter Rot Caused by Two Colletotrichum spp.
}

\author{
Alan R. Biggs, West Virginia University, Kearneysville Tree Fruit Research and Education Center, P.O. Box 609, \\ Kearneysville 25430
}

\begin{abstract}
Biggs, A. R. 1999. Effects of calcium salts on apple bitter rot caused by two Colletotrichum spp. Plant Dis. 83:1001-1005.

The effects of three calcium salts on conidial germination, germ tube elongation, growth in vitro, and infectivity in the laboratory and field were studied for the apple bitter rot pathogens, Colletotrichum gloeosporioides and C. acutatum. Calcium chloride, calcium propionate, and calcium silicate at $1,000 \mu \mathrm{g}$ of calcium per $\mathrm{ml}$ had no effect on conidial germination; however, calcium chloride and calcium propionate inhibited germ tube growth by 41 and $50 \%$ relative to the control, respectively. All three calcium salts reduced fungal dry weight in liquid culture media. When calcium salt solutions were applied to wounded apples prior to inoculation, fruit treated with calcium chloride and calcium propionate exhibited 30\% smaller lesions than those treated with calcium silicate or the control, which were similar. Fruit treated with calcium chloride and calcium propionate exhibited delayed formation of acervuli relative to the control and calcium silicate, which were similar. When fruit were inoculated with varying concentrations of conidia, from $1 \times 10^{3}$ to $1 \times 10^{5}$ conidia per $\mathrm{ml}$, fruit treated with calcium chloride exhibited reduced incidence of infection after inoculations with $1 \times 10^{3}$ conidia per ml. In all tests at $1 \times$ $10^{4}$ and $1 \times 10^{5}$ conidia per $\mathrm{ml}$, the control and calcium salt treatments resulted in similar incidences of infection after inoculations. In six field trials, where fruit received three weekly dilute applications of calcium solutions, fruit treated with calcium salts and then inoculated with conidia of either C. gloeosporioides or $C$. acutatum exhibited lower incidences of infection when compared with control fruit. These experiments demonstrate that calcium salts have suppressive activity against the bitter rot pathogens and could be used as part of a disease management program.
\end{abstract}

Additional keywords: anthracnose, Glomerella cingulata

Bitter rot, caused by Colletotrichum gloeosporioides (teleomorph $=$ Glomerella cingulata) and C. acutatum, is a destructive fruit rot of apple and pear in the southern, central, and mid-Atlantic regions of the United States and in most countries where these fruits are grown (13). Prior to the development of effective fungicides, disease of apples could be extensive, with entire crops lost following periods of warm, wet weather. With the advent of modern fungicides, the disease is less prevalent than in the past, largely due to the efficacy of the ethylene-bis dithiocarbamates (EBDCs). However, with the greater restrictions on these fungicides since their reregistration in 1994, significant fruit losses from bitter rot have occurred in years when weather conditions have been favorable and less effective fungicides were used. Although disease control is achieved primarily with the use

Corresponding author: A. R. Biggs

E-mail: abiggs2@wvu.edu

Scientific article 2724 of the West Virginia Agricultural and Forestry Experiment Station.

Accepted for publication 13 July 1999.

Publication no. D-1999-0824-01R

(C) 1999 The American Phytopathological Society of fungicides, orchard sanitation is an integral part of disease management.

Application of supplemental calcium to apples is a routine practice in orchards that are prone to calcium-related nutritional disorders such as cork spot and bitter pit. The most common form of calcium supplement is calcium chloride (as a $75 \%$ food-grade flake); however, many proprietary products containing calcium in other forms, or combined with other nutrients, are available. Calcium supplements are most often applied beginning 2 to 4 weeks after petal fall and may continue through the preharvest period for as many as eight applications. Recommended rates of calcium chloride range from 17 to 56 $\mathrm{kg} / \mathrm{ha}$ per year based on the potential severity of nutritional disorders.

In addition to controlling nutritional disorders, increasing the calcium content of fruits and vegetables increases their storage life. This effect is thought to be due mainly to the role of calcium in ameliorating physiological disorders and thus indirectly reducing pathogen activity $(1,11)$. Much of the research with apples on enhancing storage quality and reducing decay with calcium supplementation has been done in the postharvest environment (6-10). Few studies have examined the potential role of calcium supplementation in the preharvest period for reducing disease. These trials were conducted to determine whether the use of $\mathrm{Ca}$ salts had any effect on fungal growth and disease incidence in vitro or in vivo.

\section{MATERIALS AND METHODS}

Fungal isolates. Fungal isolates were obtained from K. S. Yoder (Virginia Tech, Winchester Agricultural Research and Extension Center) and were maintained on potato dextrose agar (PDA) in petri dishes. Isolates were subcultured weekly and maintained at $22^{\circ} \mathrm{C}$ during the periods in which experiments were conducted. Conidia for inoculum were harvested from 7 day-old cultures in all the studies described below. Longer term storage of cultures was on PDA in culture tubes maintained at $4^{\circ} \mathrm{C}$. Conidia were harvested by flooding the dishes with sterile distilled water, scraping the plates with a rubber spatula, and filtering the suspension through four layers of sterile cheesecloth. The desired concentrations of conidia were prepared by dilution from the original suspensions after counting with a hemacytometer.

Effects of calcium salts on spore germination, germ tube elongation, and mycelial growth in vitro. Pure calcium salts used in this study were calcium chloride, calcium propionate, and calcium silicate. These salts were selected based on the results of a preliminary study in which a broad range of calcium salts was tested for in vitro activity on growth of $C$. gloeosporioides and $C$. acutatum. To assess the effects of calcium salts on germination of conidia, salts were prepared in sterile deionized distilled water and were added to autoclaved warm $\left(45\right.$ to $\left.55^{\circ} \mathrm{C}\right) 2 \%$ water agar (WA) to provide a final concentration of $1,000 \mathrm{mg}$ of calcium per liter. The medium was poured into 9-cm-diameter petri dishes. WA medium not supplemented with calcium was included as a control. Five $30-\mu l$ droplets of freshly prepared conidia suspension of either fungus were placed on each of three replicate dishes. To assess germination, 50 conidia were examined from each droplet after $8 \mathrm{~h}$ at $22^{\circ} \mathrm{C}$. A conidium was considered germinated if the length of the germ tube was more than half the length of the conidium. This experiment was conducted twice. To assess the effects of calcium salts on germ tube elongation, the procedure described above was used, except that 25 germ tubes from each droplet were measured with an ocular micrometer after $14 \mathrm{~h}$ at $22^{\circ} \mathrm{C}$. This experiment was conducted twice. Data were analyzed with analysis of variance, 
and means were separated with the WallerDuncan $k$-ratio $t$ test (SAS Institute, Cary, NC).

To assess the effects of calcium salts on mycelial growth, salts were prepared in sterile deionized distilled water and were added to autoclaved warm $\left(45\right.$ to $\left.55^{\circ} \mathrm{C}\right) 2 \%$ potato dextrose broth (PDB) to provide a range of concentrations from 600 to 1,200 $\mathrm{mg}$ of calcium per liter. The media were poured into $250-\mathrm{ml}$ stationary flasks. A $30-$ $\mu \mathrm{l}$ drop of a suspension of $1 \times 10^{5}$ conidia from either fungus was placed in each flask. Flasks were incubated in the dark at $20 \pm 2{ }^{\circ} \mathrm{C}$, and growth was assessed after 14 days by determining the dry weight of the mycelium. The experiment was performed three times with three replicate flasks per treatment, and results were subjected to regression analysis (SAS).

Effects of calcium salts on infection of wounded apple fruit and rate of formation of acervuli. In 1996, harvested fruit of apple cultivar Nittany were placed on paper trays in plastic tubs. Each fruit was surface-disinfested with $70 \%$ ethanol and then wounded by piercing the epidermis with a sharpened 7-mm-diameter cork borer and removing the disk of epidermis with a sterile scalpel. Solutions of calcium chloride, calcium propionate, calcium silicate (each at $1,000 \mathrm{mg}$ of calcium per liter), or sterile deionized water were sprayed on the fruit until the surfaces were saturated. Sprayed fruit were then allowed to air-dry, after which $30 \mu \mathrm{l}$ of a suspension of $1 \times 10^{5}$ conidia from either fungus was placed in each wound. Lids were placed on the tubs to help maintain a high relative humidity, and the diameter of the resulting lesions was measured 7 and 14 days after inoculation. Each lesion was measured twice at right angles, and the two values were averaged to obtain the lesion diameter. Periodic observations were made on the development of acervuli on the surfaces of lesions. Acervulus development was rated on a 0 to 3 scale, with $0=$ no acervuli initials, $1=$ black acervuli initials visible, 2 $=$ pigmented acervuli present but not viscid, and $3=$ pigmented acervuli with a viscid appearance. Each treatment for each fungus consisted of three replicates of 10 fruit each. This experiment was conducted three times. Data on lesion diameter were subjected to analysis of variance, and means were separated with the WallerDuncan $k$-ratio $t$ test (SAS). Differences among categorical rankings for acervulus development were determined with the Kruskal-Wallis test (SAS).

In a second set of experiments, fruit were prepared as above and then were inoculated with varying concentrations of conidia ranging from $1 \times 10^{3}$ to $1 \times 10^{5}$ conidia per ml. This experiment was conducted four times. The first trial of this experiment was conducted in 1996 with the cultivar Nittany, and the remaining trials were conducted in 1997 with the cultivar Golden Delicious. Data on disease incidence and lesion diameter were subjected to analysis of variance, and means were separated with the WallerDuncan $k$-ratio $t$ test (SAS).

Effects of field applications of calcium salts to apple fruit on the incidence and severity of bitter rot. In 1997 (Golden Delicious) and 1998 (Nittany), fruit on trees that had not been sprayed with fungicides were sprayed with calcium chloride, calcium propionate, or calcium silicate (1997 only) or calcium hydroxide (1998 only) at $1,200 \mathrm{mg}$ of calcium per liter. Each set of 10 fruit per treatment was sprayed to runoff with $1,200 \mathrm{mg}$ of calcium per liter $+0.1 \%$ Nufilm 17 (Miller Chemical Co., Biglerville, PA) weekly for 3 consecutive weeks. Preliminary tests with Nufilm 17 were conducted to determine that the adjuvant had no effect on fruit infection by Colletotrichum spp. The day following the third calcium application, attached fruit were inoculated with either C. gloeosporioides or C. acutatum. Inoculations were made by preparing suspensions of conidia as described above, immersing 2.5-cm-wide cheesecloth strips (4 layers thick) into the suspensions, and wrapping the strips around the widest part of the fruit. The strips were secured with one layer each of plastic wrap and aluminum foil. The inoculum was removed after 5 to 7 days. Controls included fruit sprayed with distilled water and inoculated, and nonsprayed fruit that were inoculated without conidia. The experiment was conducted three times in each of the two years. All fruit from the three trials in each year were harvested at the normal harvest date for the particular cultivar. The harvested fruit were arranged in labeled trays and were observed weekly for disease incidence (presence of bitter rot determined from visible sporulation or reisolation when necessary). Data on disease incidence were subjected to analysis of variance, and means were separated with the Waller-Duncan $k$-ratio $t$ test (SAS). The

Table 1. Length of Colletotrichum gloeosporioides and C. acutatum germ tubes from conidia placed on water agar amended with $1,000 \mathrm{mg}$ of calcium per liter from calcium chloride, calcium propionate, and calcium silicate

\begin{tabular}{lcc}
\hline & \multicolumn{2}{c}{ Germ tube length $(\boldsymbol{\mu m})$} \\
\cline { 2 - 3 } Treatment & C. gloeosporioides & C. acutatum \\
\hline Ca chloride & $46.9 \mathrm{~b}$ 学学 & $49.7 \mathrm{c}$ \\
Ca propionate & $41.1 \mathrm{~b}$ & $21.5 \mathrm{~d}$ \\
Ca silicate & $73.5 \mathrm{a}$ & $58.9 \mathrm{~b}$ \\
Water agar & $79.6 \mathrm{a}$ & $109.8 \mathrm{a}$ \\
$\quad$ control & & \\
\hline
\end{tabular}

$y$ Values are the means of 150 measurements (25 germ tubes measured from three replicates with data from two experiments combined).

${ }^{\mathrm{z}}$ Letters denote significant differences among means in columns according to the WallerDuncan test $(P=0.05)$. effect of the trial was determined to be not significant (Bartlett's test), so data from the separate trials were combined.

\section{RESULTS}

Effects of calcium salts on conidial germination, germ tube elongation, and mycelial growth in vitro. At $1,000 \mathrm{mg}$ of calcium per liter, calcium chloride, calcium propionate, and calcium silicate had no effect on conidial germination in vitro. Calcium chloride inhibited germ tube growth of C. gloeosporioides by $41 \%$ and of $C$. acutatum by $50 \%$ relative to the control, and calcium propionate inhibited germ tube growth of C. gloeosporioides by $48 \%$ and of $C$. acutatum by $80 \%$ (Table 1 ). In liquid culture media, calcium chloride and
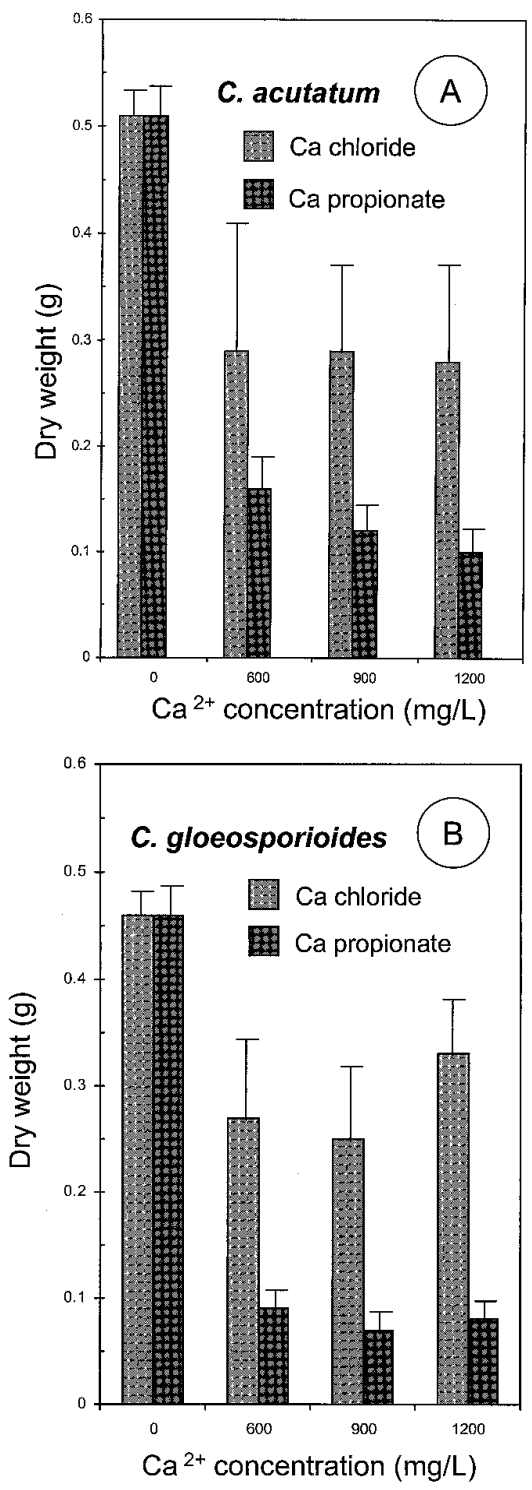

Fig. 1. Dry weight of mycelium of Colletotrichum acutatum (A) and C. gloeosporioides (B) after 14 days in potato dextrose broth amended with calcium chloride (light bars) or calcium propionate (dark bars). 
calcium propionate reduced fungal dry weight (Fig. 1).

Effects of calcium salts on infection of wounded apple fruit and rate of formation of acervuli. Wounds that were treated with calcium chloride and then inoculated exhibited 20 to $29 \%$ smaller lesions than the control for $C$. acutatum and were 22 to $26 \%$ smaller than the control for $C$. gloeosporioides (Table 2). Similarly, wounds treated with calcium propionate had lesions that were $26 \%$ smaller than the control for $C$. acutatum and 24 to $34 \%$ smaller than the control for C. gloeosporioides (Table 2). Lesion diameter at wounds treated with calcium silicate was similar to the control, except in trial 2 with C. gloeosporioides, in which lesions were $17 \%$ smaller (Table 2). With $C$. acutatum, lesions that developed following treatment had delayed formation of acervuli when compared with the control (Table 2). The delay in acervulus formation was not observed with $C$. gloeosporioides.

Wounded fruit of both cultivars pretreated with calcium chloride and then inoculated with varying concentrations of conidia exhibited reduced incidence of infection (62 to $87 \%$ less than the control) after inoculations with $1 \times 10^{3}$ conidia per $\mathrm{ml}$ of either fungus (Table 3 ). Golden Delicious, but not Nittany, fruit treated with calcium propionate and calcium silicate also exhibited reduced disease incidence after inoculation with $1 \times 10^{3}$ conidia per $\mathrm{ml}$ of either fungus (Table 3 ). In tests at 1 $\times 10^{4}$ and $1 \times 10^{5}$ conidia per $\mathrm{ml}$, no consistent treatment effects were observed, and with only three exceptions among the 32 treatment combinations, the control and calcium salt treatments had similar incidences of infection after inoculation of wounded fruit.

Fruit of both cultivars treated with calcium chloride exhibited smaller lesions (63 to $72 \%$ ) after inoculations with $1 \times 10^{3}$ conidia per $\mathrm{ml}$ of $C$. acutatum (Table 4). Similarly, lesions were 30 to $75 \%$ smaller after inoculations of calcium chloridetreated fruit with $1 \times 10^{3}$ conidia of $C$. gloeosporioides per ml (Table 4). Fruit of both cultivars treated with calcium propionate exhibited smaller lesions (22 to $70 \%$ ) after inoculations with $1 \times 10^{3}$ conidia of C. acutatum per $\mathrm{ml}$ (Table 4), whereas lesions were $50 \%$ smaller for Golden Delicious fruit treated with calcium propionate and inoculated with $C$. gloeosporioides (Table 4). Golden Delicious, but not Nittany, fruit also exhibited reduced severity after inoculation with all three inoculum concentrations of either fungus (Table 4). For Nittany, in tests at $1 \times 10^{4}$ and $1 \times 10^{5}$ conidia per $\mathrm{ml}$, the control and calcium salt treatments exhibited similar infection severity.

Effects of field applications of calcium salts to apple fruit on the incidence and severity of bitter rot. In six separate field trials conducted over 2 years, fruit treated with weekly dilute applications of calcium salts and then inoculated with conidia of either C. gloeosporioides or C. acutatum had lower incidences of infection com-

pared with the controls (Tables 5 and 6). In 1997, for Golden Delicious inoculated with C. acutatum, most infections on control fruit became visible between the first and

Table 2. Lesion diameter at 7 days and acervulus development at 7 and 9 days after inoculating wounded Nittany apples with conidia of Colletotrichum gloeosporioides or C. acutatum

\begin{tabular}{|c|c|c|c|c|c|c|}
\hline \multirow[b]{3}{*}{ Treatment } & \multicolumn{3}{|c|}{ C. gloeosporioides } & \multicolumn{3}{|c|}{ C. acutatum } \\
\hline & \multirow{2}{*}{$\begin{array}{l}\text { Lesion diam. } \\
\text { (mm) }\end{array}$} & \multicolumn{2}{|c|}{ Acervuli rating $^{x}$} & \multirow{2}{*}{$\begin{array}{l}\text { Lesion diam. } \\
\quad(\mathrm{mm})\end{array}$} & \multicolumn{2}{|c|}{ Acervuli rating } \\
\hline & & 7 days & 9 days & & 7 days & 9 days \\
\hline \multicolumn{7}{|l|}{ Trial 1} \\
\hline Ca propionate & $17.9 \mathrm{~b}^{\mathrm{y}, \mathrm{z}}$ & 0.5 & 1.0 & $19.1 \mathrm{~b}$ & 0 & 1.5 \\
\hline Ca chloride & $18.4 \mathrm{~b}$ & 0.4 & 1.1 & $20.6 \mathrm{~b}$ & 0 & 1.6 \\
\hline Ca silicate & $22.8 \mathrm{a}$ & 0.6 & 1.3 & $24.9 \mathrm{a}$ & 0.2 & 2.0 \\
\hline Control & $23.6 \mathrm{a}$ & $\begin{array}{c}0.9 \\
\chi^{2}=5.2 \\
P \leq 0.16\end{array}$ & $\begin{array}{c}1.3 \\
\chi^{2}=3.5 \\
P \leq 0.32\end{array}$ & $25.8 \mathrm{a}$ & $\begin{array}{c}0.4 \\
\chi^{2}=9.7 \\
P \leq 0.02\end{array}$ & $\begin{array}{c}2.2 \\
\chi^{2}=7.6 \\
P \leq 0.05\end{array}$ \\
\hline \multicolumn{7}{|l|}{ Trial 2} \\
\hline Ca propionate & $16.6 \mathrm{c}$ & 0.4 & 1.1 & $17.4 \mathrm{~b}$ & 0 & 1.0 \\
\hline $\mathrm{Ca}$ chloride & $18.6 \mathrm{bc}$ & 0.6 & 1.2 & $16.6 \mathrm{~b}$ & 0.1 & 1.1 \\
\hline Ca silicate & $20.9 \mathrm{~b}$ & 0.6 & 1.2 & $22.4 \mathrm{a}$ & 0.2 & 1.5 \\
\hline Control & $25.2 \mathrm{a}$ & $\begin{array}{c}0.9 \\
\chi^{2}=6.9 \\
P \leq 0.08\end{array}$ & $\begin{array}{c}1.2 \\
\chi^{2}=0.3 \\
P \leq 0.96\end{array}$ & $23.7 \mathrm{a}$ & $\begin{array}{c}0.7 \\
\chi^{2}=7.6 \\
P \leq 0.05\end{array}$ & $\begin{array}{c}2.1 \\
\chi^{2}=7.7 \\
P \leq 0.05\end{array}$ \\
\hline
\end{tabular}

${ }^{x}$ Acervuli rated on a scale of 0 to 3 with $0=$ no acervuli initials, $1=$ black acervuli initials visible, 2 $=$ pigmented acervuli present but not viscid, and $3=$ pigmented acervuli with a viscid appearance. Differences among categorical rankings for acervulus developments were determined with KruskalWallis $\chi^{2}$ test.

$\mathrm{y}$ Values are means of 30 measurements.

${ }^{\mathrm{z}}$ Letters denote significant differences among means in columns within trial according to the WallerDuncan test $(P=0.05)$.

Table 3. Incidence (\%) of bitter rot on Nittany or Golden Delicious apple fruit 7 and 9 days, respectively, after inoculation of calcium salt-treated wounds with varying numbers of conidia of Colletotrichum gloeosporioides or C. acutatum

\begin{tabular}{|c|c|c|c|c|c|c|}
\hline \multirow[b]{2}{*}{ Treatment } & \multicolumn{3}{|c|}{ C. gloeosporioides conidia/ml } & \multicolumn{3}{|c|}{ C. acutatum conidia/ml } \\
\hline & 1,000 & 10,000 & 100,000 & 1,000 & 10,000 & 100,000 \\
\hline \multicolumn{7}{|l|}{ Nittany } \\
\hline Ca propionate & $53.3 \mathrm{a}^{\mathrm{y}, \mathrm{z}}$ & $93.3 \mathrm{a}$ & $100 \mathrm{a}$ & $80.0 \mathrm{a}$ & $100 \mathrm{a}$ & $100 \mathrm{a}$ \\
\hline Ca chloride & $13.3 \mathrm{~b}$ & $100 \mathrm{a}$ & $100 \mathrm{a}$ & $13.3 \mathrm{~b}$ & $93.3 \mathrm{ab}$ & $100 \mathrm{a}$ \\
\hline Ca silicate & $53.3 \mathrm{a}$ & $93.3 \mathrm{a}$ & $66.7 \mathrm{a}$ & $100 \mathrm{a}$ & $66.7 \mathrm{~b}$ & $100 \mathrm{a}$ \\
\hline Control & $46.7 \mathrm{a}$ & $100 \mathrm{a}$ & $100 \mathrm{a}$ & $100 \mathrm{a}$ & $100 \mathrm{a}$ & $100 \mathrm{a}$ \\
\hline \multicolumn{7}{|l|}{ Golden Delicious } \\
\hline Ca propionate & $3.0 \mathrm{~b}$ & $40.0 \mathrm{~b}$ & $73.0 \mathrm{a}$ & $32.5 \mathrm{~b}$ & $86.5 \mathrm{ab}$ & $100 \mathrm{a}$ \\
\hline Ca chloride & $20.0 \mathrm{~b}$ & $73.0 \mathrm{a}$ & $90.0 \mathrm{a}$ & $34.5 \mathrm{~b}$ & $76.0 \mathrm{~b}$ & $98.5 \mathrm{a}$ \\
\hline Ca silicate & $17.0 \mathrm{~b}$ & $33.0 \mathrm{~b}$ & $87.0 \mathrm{a}$ & $37.5 \mathrm{~b}$ & $91.0 \mathrm{a}$ & $100 \mathrm{a}$ \\
\hline Control & $53.0 \mathrm{a}$ & $80.0 \mathrm{a}$ & $100 \mathrm{a}$ & $100 \mathrm{a}$ & $100 \mathrm{a}$ & $100 \mathrm{a}$ \\
\hline
\end{tabular}

y Values are means of 30 measurements.

${ }^{\mathrm{z}}$ Letters denote significant differences among means in columns within apple cultivar according to the Waller-Duncan test $(P=0.05)$.

Table 4. Severity (mean lesion diameter, $\mathrm{mm}$ ) of bitter rot on Nittany or Golden Delicious apple fruit 7 and 9 days, respectively, after inoculation of calcium salt-treated wounds with varying numbers of conidia of Colletotrichum gloeosporioides or C. acutatum

\begin{tabular}{|c|c|c|c|c|c|c|}
\hline \multirow[b]{2}{*}{ Treatment } & \multicolumn{3}{|c|}{ C. gloeosporioides conidia/ml } & \multicolumn{3}{|c|}{ C. acutatum conidia/ml } \\
\hline & 1,000 & 10,000 & 100,000 & 1,000 & 10,000 & 100,000 \\
\hline \multicolumn{7}{|l|}{ Nittany } \\
\hline Ca propionate & $5.2 \mathrm{a}^{\mathrm{y}, \mathrm{z}}$ & $5.6 \mathrm{a}$ & $6.8 \mathrm{a}$ & $6.4 \mathrm{a}$ & $6.4 \mathrm{a}$ & $6.8 \mathrm{a}$ \\
\hline Ca chloride & $1.3 \mathrm{~b}$ & $5.1 \mathrm{a}$ & $7.1 \mathrm{a}$ & $2.2 \mathrm{~b}$ & $5.1 \mathrm{a}$ & $6.6 \mathrm{a}$ \\
\hline Ca silicate & $4.4 \mathrm{a}$ & $6.8 \mathrm{a}$ & $6.0 \mathrm{a}$ & $6.4 \mathrm{a}$ & $6.2 \mathrm{a}$ & $6.5 \mathrm{a}$ \\
\hline Control & $5.2 \mathrm{a}$ & $8.1 \mathrm{a}$ & $8.4 \mathrm{a}$ & $7.8 \mathrm{a}$ & $7.8 \mathrm{a}$ & $8.5 \mathrm{a}$ \\
\hline \multicolumn{7}{|c|}{ Golden Delicious } \\
\hline Ca propionate & $5.9 \mathrm{c}$ & $11.1 \mathrm{c}$ & $15.9 \mathrm{~b}$ & $5.4 \mathrm{c}$ & $9.2 \mathrm{c}$ & $14.6 \mathrm{c}$ \\
\hline $\mathrm{Ca}$ chloride & $8.3 \mathrm{~b}$ & $13.7 \mathrm{~b}$ & $14.7 \mathrm{~b}$ & $6.6 \mathrm{~b}$ & $11.5 \mathrm{~b}$ & $15.1 \mathrm{c}$ \\
\hline Ca silicate & $7.8 \mathrm{~b}$ & $11.5 \mathrm{c}$ & $15.7 \mathrm{~b}$ & $7.0 \mathrm{~b}$ & $12.0 \mathrm{~b}$ & $17.1 \mathrm{~b}$ \\
\hline Control & $11.8 \mathrm{a}$ & $18.8 \mathrm{a}$ & $38.9 \mathrm{a}$ & $18.1 \mathrm{a}$ & $21.5 \mathrm{a}$ & $27.2 \mathrm{a}$ \\
\hline
\end{tabular}

y Values are means of 30 measurements.

${ }^{\mathrm{z}}$ Letters denote significant differences among means in columns within apple cultivar according to the Waller-Duncan test $(P=0.05)$. 
second weeks after harvest, reaching a mean of $94 \%$ incidence after the second week (Table 5). In comparison, mean incidences of infection at 2 weeks postharvest for fruit treated with calcium silicate, calcium chloride, and calcium propionate were 46,18 , and $8 \%$, respectively. All three salt treatments were significantly different from the control $(P=0.05)$, and calcium chloride and calcium propionate were similar to each other and different from calcium silicate $(P=0.05)$ in reducing disease incidence. For $C$. gloeosporioides, mean incidence of infection at 2 weeks postharvest in the control treatment was $85 \%$ compared with 31,8 , and $7 \%$ for calcium silicate, calcium chloride, and calcium propionate, respectively. All three salt treatments were significantly different from the control $(P=0.05)$, and calcium chloride and calcium propionate were similar to each other and different from calcium silicate $(P=0.05)$ (Table 5).

Table 5. Incidence of bitter rot after harvest on Golden Delicious apple fruit that received three weekly applications of calcium solutions in June (trial 1), July (trial 2), or August (trial 3) followed by inoculation with conidia of either Colletotrichum gloeosporioides or C. acutatum

\begin{tabular}{lcccc}
\hline & \multicolumn{4}{c}{ Disease incidence $(\%)$} \\
\cline { 2 - 5 } Treatment & $\mathbf{1}$ week & 2 weeks & 3 weeks & 4 weeks \\
\hline C. acutatum & & & & \\
Ca propionate & $0 \mathrm{c} y, \mathrm{z}$ & $8.4 \mathrm{c}$ & $34.8 \mathrm{~d}$ & $77.0 \mathrm{c}$ \\
Ca chloride & $0 \mathrm{c}$ & $18.3 \mathrm{c}$ & $47.1 \mathrm{c}$ & $84.1 \mathrm{~b}$ \\
Ca silicate & $7.8 \mathrm{~b}$ & $45.9 \mathrm{~b}$ & $64.8 \mathrm{~b}$ & $100 \mathrm{a}$ \\
Control & $22.7 \mathrm{a}$ & $94.4 \mathrm{a}$ & $100 \mathrm{a}$ & $100 \mathrm{a}$ \\
C. gloeosporioides & & & & \\
Ca propionate & $0 \mathrm{~b}$ & $6.7 \mathrm{c}$ & $40.2 \mathrm{c}$ & $52.8 \mathrm{c}$ \\
Ca chloride & $0 \mathrm{~b}$ & $7.9 \mathrm{c}$ & $43.1 \mathrm{c}$ & $83.3 \mathrm{~b}$ \\
Ca silicate & $7.8 \mathrm{ab}$ & $30.9 \mathrm{~b}$ & $56.1 \mathrm{~b}$ & $100 \mathrm{a}$ \\
Control & $16.7 \mathrm{a}$ & $85.3 \mathrm{a}$ & $100 \mathrm{a}$ & $100 \mathrm{a}$ \\
\hline
\end{tabular}

y Values are the percentage incidence from 90 fruit ( 3 replicates of 10 fruit each in each of 3 trials); however, in some instances, fruit abscised prematurely, resulting in some replicates with fewer than 10 fruit. Fruit was harvested on 9 September 1997 and assessed at weekly intervals thereafter. Inoculations with $1 \times 10^{5}$ conidia per ml were made on 1 July, 5 August, and 2 September for trials 1 , 2 , and 3 , respectively.

${ }^{\mathrm{z}}$ Letters denote significant differences among means in columns within fungus according to the Waller-Duncan test $(P=0.05)$.

Table 6. Incidence (\%) of bitter rot at various times after harvest on Nittany apple fruit that received three weekly applications of calcium solutions followed by inoculation with conidia of either Colletotrichum gloeosporioides or C. acutatum

\begin{tabular}{lcccc}
\hline & \multicolumn{4}{c}{ Disease incidence (\%) } \\
\cline { 2 - 5 } Treatment & Harvest & 1 week & 2 weeks & 3 weeks \\
\hline C. acutatum & & & & \\
Ca propionate & $1.1 \mathrm{~b}, \mathrm{y}$ & $4.4 \mathrm{~b}$ & $7.8 \mathrm{~b}$ & $17.8 \mathrm{~b}$ \\
Ca chloride & $2.2 \mathrm{~b}$ & $8.9 \mathrm{~b}$ & $18.9 \mathrm{~b}$ & $23.3 \mathrm{~b}$ \\
Ca hydroxide & $2.2 \mathrm{~b}$ & $11.1 \mathrm{~b}$ & $26.7 \mathrm{~b}$ & $27.8 \mathrm{~b}$ \\
Control & $17.8 \mathrm{a}$ & $51.1 \mathrm{a}$ & $56.7 \mathrm{a}$ & $71.1 \mathrm{a}$ \\
C. gloeosporioides & & & & \\
Ca propionate & $0 \mathrm{~b}$ & $3.3 \mathrm{~b}$ & $7.8 \mathrm{~b}$ & $22.2 \mathrm{ab}$ \\
Ca chloride & $1.1 \mathrm{~b}$ & $5.6 \mathrm{~b}$ & $17.8 \mathrm{~b}$ & $25.6 \mathrm{ab}$ \\
Ca hydroxide & $1.1 \mathrm{~b}$ & $8.9 \mathrm{~b}$ & $12.2 \mathrm{~b}$ & $13.3 \mathrm{~b}$ \\
Control & $13.3 \mathrm{a}$ & $31.1 \mathrm{a}$ & $44.4 \mathrm{a}$ & $51.1 \mathrm{a}$ \\
\hline
\end{tabular}

${ }^{y}$ Values are the percentage incidence from 90 fruit ( 3 replicates of 10 fruit each in each of 3 trials); however, in some instances, fruit abscised prematurely, resulting in some replicates with fewer than 10 fruit. Fruit were harvested on 1 October 1998 and assessed at weekly intervals. Inoculations with $1 \times 10^{5}$ conidia per ml were made on 1 July, 25 August, and 15 September for trials 1, 2, and 3, respectively.

${ }^{\mathrm{z}}$ Letters denote significant differences among means in columns within fungus according to the Waller-Duncan test $(P=0.05)$.

\section{DISCUSSION}

The results of this study demonstrate that calcium salts directly suppress the bitter rot pathogens, C. gloeosporioides and $C$. acutatum. Suppressive effects include reduced germ tube growth, reduced mycelial growth in vitro, and reduced severity of infection of host tissues pretreated with calcium. Also, disease incidence in Golden Delicious, but not in Nittany, was reduced at the lowest inoculum concentration tested. The high susceptibility of Nittany (3) to the bitter rot pathogens may have resulted in a higher frequency of successful infections at the lowest inoculum concentration compared with Golden Delicious, which is more resistant. Although calcium salts did not reduce spore germination in this study, reduced germination of Penicillium digitatum spores exposed to calcium chloride has been observed (12), as well as reduced germination and germ tube growth of $P$. expansum and Botrytis cinerea (14). Calcium salts also have been shown to reduce mycelial growth in vitro and reduce incidence and severity of infection of peach fruits and shoots by Monilinia fructicola and Leucostoma persoonii, respectively $(2,4,5)$.

In the present study, we observed direct inhibition of germ tube elongation and inhibition of mycelial growth in in vitro assays, and it is likely that these effects occur in vivo in the presence of free calcium ions. The mechanisms by which calcium salts inhibit germ tube and mycelial growth are not known. One hypothesis is that high external concentrations of $\mathrm{Ca}^{2+}$ may lead to increased concentration of $\mathrm{Ca}^{2+}$ in the cytosol (12). Since maintenance of low basal concentrations of internal $\mathrm{Ca}^{2+}$ is essential for normal cell functions, organisms with the inability to regulate intracellular $\mathrm{Ca}^{2+}$ may exhibit compromised growth and development. Calcium ions may reduce the incidence of fungal infection by directly inhibiting fungal growth and by inhibiting cell wall-degrading enzymes produced by the pathogens $(4,5,9,12)$.

Apples in the mid-Atlantic region are host to a myriad of disease-causing fungi. Chemical management of apple diseases is usually accomplished so that multiple diseases are controlled with each fungicide application. The major fungal diseases and pathogens during the early part of the growing season are apple scab (Venturia inaequalis), powdery mildew (Podosphaera leucotricha), and cedar-apple rust (Gymnosporangium juniperi-virginianae). After the fruit are set, apple scab can continue to be a problem if scab lesions are present on foliage, and powdery mildew can continue to develop, especially on susceptible cultivars. As fruit develop, they are susceptible to the "summer diseases," which include bitter rot, white rot (Botryosphaeria dothidea), black rot (B. obtusa), sooty blotch (a complex of fungal organisms), and fly- 
speck (Zygophiala jamaicensis). The role of calcium supplementation in the integrated management of apple diseases is not well defined because few organisms among the myriad of apple pathogens have been examined in sufficient detail. Most of our current knowledge pertains to the postharvest pathogens discussed above. In the preharvest environment, calcium chloride and other calcium salts have shown suppressive activity against $V$. inaequalis, $P$. leucotricha, and G. juniperi-virginianae in research trials (A. R. Biggs, unpublished data); however, the early part of the growing season, when these fungi pose the greatest threat, is not when calcium applications would be made for managing calcium-related deficiency disorders, nor does calcium alone provide sufficient suppression of these diseases to prevent economic losses. In the middle to late part of the growing season, when calcium chloride would normally be applied for its fruit quality effects, no reduction in incidence of sooty blotch or flyspeck has been observed, although their severity is often reduced (A. R. Biggs, unpublished). There are no data on the effects of calcium salts on the incidence of white rot or black rot. Although further research is required, calcium salts may have a future role in disease management of fruit destined for processing, particularly in years when inoculum is low and environ- mental conditions are not highly favorable.

\section{ACKNOWLEDGMENTS}

The assistance of Isabelle Myers, Rosemary Nickerson, and Erin Fultineer is gratefully acknowledged. This work was supported by the West Virginia Tree Fruit Assessment Board. Fruit for some of the experiments was kindly provided by Summit Point Raceway Orchards.

\section{LITERATURE CITED}

1. Bateman, D. F., and Lumsden, R. D. 1965. Relation of calcium content and nature of the pectic substances in bean hypocotyls of different ages to susceptibility of an isolate of Rhizoctonia solani. Phytopathology 55:734738.

2. Biggs, A. R., El-Kholi, M. M., and El-Neshawy, S. 1994. Effect of calcium salts on growth, pectic enzyme activity, and colonization of peach twigs by Leucostoma persoonii. Plant Dis. 78:886-890.

3. Biggs, A. R., El-Kholi, M. M., El-Neshawy, S., and Nickerson, R. 1997. Effects of calcium salts on growth, polygalacturonase activity, and infection of peach fruit by Monilinia fructicola. Plant Dis. 81:399-403.

4. Biggs, A. R., Ingle, M., and Solihati, W. D. 1993. Control of Alternaria infection of fruit of apple cultivar Nittany with calcium chloride and fungicides. Plant Dis. 77:976-980.

5. Biggs, A. R., and Peterson, C. A. 1990. Effect of chemical applications to peach bark wounds on accumulation of lignin and suberin and susceptibility to Leucostoma persoonii. Phytopathology 80:861-865.

6. Conway, W. S. 1982. Effect of postharvest calcium treatment on decay of Delicious apples. Plant Dis. 66:402-403.
7. Conway, W. S., Greene, G. M., II, and Hickey, K. D. 1987. Effects of preharvest and postharvest calcium treatments of peaches on decay caused by Monilinia fructicola. Plant Dis. 71:1084-1086.

8. Conway, W. S., Gross, K. C., and Sams, C. E. 1987. Relationship of bound calcium and inoculum concentration to the effect of postharvest calcium treatment on decay of apples by Penicillium expansum. Plant Dis. 71:78-80.

9. Conway, W. S., and Sams, C. E. 1984. Possible mechanisms by which postharvest calcium treatment reduces decay in apples. Phytopathology 74:208-210.

10. Conway, W. S., Sams, C. E., Brown, G. A., Beavers, W. B., Tobias, R. B., and Kennedy, L. S. 1994. Pilot test for the commercial use of postharvest pressure infiltration of calcium into apples to maintain fruit quality in storage. HortTechnology 4:239-243.

11. Conway, W. S., Sams, C. E., McGuire, R. G., and Kelman, A. 1992. Calcium treatment of apples and potatoes to reduce postharvest decay. Plant Dis. 76:329-334.

12. Droby, S., Wisniewski, M. E., Cohen, L., Weiss, B., Touitou, D., Eilam, Y., and Chalutz, E. 1997. Influence of $\mathrm{CaCl}_{2}$ on Penicillium digitatum, grapefruit peel tissue, and biocontrol activity of Pichia guilliermondii. Phytopathology 87:310-315.

13. Sutton, T. B. 1990. Bitter Rot. Pages 15-16 in: Compendium of Apple and Pear Diseases, A L. Jones and H. S. Aldwinckle, eds. American Phytopathological Society, St. Paul, MN.

14. Wisniewski, M. E., Droby, S., Chalutz, E., and Elam, Y. 1995. Effects of $\mathrm{Ca}^{2+}$ and $\mathrm{Mg}^{2+}$ on Botrytis cinerea and Penicillium expansum in vitro and on the biocontrol activity of Candida oleophila. Plant Pathol. 44:1016-1024 